to physical oceanography and to deep-sea apparatus. Here there is a great collection of dredges, tow-nets, showing the various devices for opening and closing at a given depth, the deep-sea traps with which the Prince has revolutionised the method of obtaining animals from the greatest depths, and many other appliances, either as used or in the form of models. At present a part of the room is occupied by a collection of specimens illustrating marine industries, such as fishing, sponge-gathering, collecting pearls, as well as the use of pearl-shell, coral, tortoise-shell, and similar products. The western hall is not yet arranged, but serves at present for classifying the various collections of mollusca, bottom-samples, \&c., which are being dealt with.

The purpose of the museum is to have all the principal collections in duplicate, one set for exhibition, the other for purposes of study. The aquariums have already been utilised for the purpose of physiological and biological researches, and the little steam-vessel Eider is available for students to familiarise themselves with the methods of practical oceanography. This little steamer, of twenty tons displacement and sixty horse-power, is fitted for working to a depth of 2000 metres, and is being used for the detailed study of the portion of the Mediterranean in the immediate vicinity of the museum.

The Oceanographical Museum, under the direction of Dr. Richard, to whose admirable description of the building and the collections we are much indebted, is only one part of the Oceanographical Institute which the enlightened munificence of the Prince of Monaco has called into existence. With the object of arousing interest in scientific marine studies in France, the Prince started a series of Iectures at the Sorbonne in 1903, and in I906 he gave perpetuity to these courses of lectures by purchasing land which was much wanted for the extension of the university buildings and presenting it to the French nation, together with a building specially devoted to university instruction in oceanography. This building is now nearing completion, and will probably be opened in the present year, or at latest in IgII. Needless to say, the university and the French Government accepted the gift with lively gratitude. Three professorships have been created in connection with it, M. A. Berget having the chair of physical oceanography, M. L. Joubin that of biological oceanography, and Dr. $\dot{P}$. Portier that of the physiology of marine life. The administrative council, under the presidency of the Prince, includes the names of several highly distinguished Frenchmen, but the committee for perfecting the institute is international, and includes representative oceanographers of all countries, Great Britain being represented by Sir John Murray, Dr. W. S. Bruce, and Mr. J. Y. Buchanan.

During the course of the Monaco gathering four important international committees met, each with the Prince as chairman, and, considering how his time was filled with State ceremonies and hospitality, it is only extraordinary enthusiasm, as well as most unusual physical strength, that enabled him to preside hour after hour, with unfailing courtesy and constant tact, over proceedings conducted in three languages. The committees were those for perfecting the Oceanographical Institute; for research in the Mediterranean, in which we understand that the Italian Government will take an active part; for research in the Atlantic, where international cooperation is hoped for, to be organised at a future meeting to be convened by the Oceanographical Institute in Paris; and, finally, for the preparation of a new edition of the Prince's bathymetrical chart of the oceans. It was decided in the new edition of this chart to suppress the indication of the nature of the bottom, which is often fallacious, to add contour lines and certain physical features on the land, and to revise the terminology.

By his researches the Prince of Monaco has won for himself a place in the foremost rank of men of science, and by enshrining the results in the monumental buildings at Monaco and Paris he has invested his labours with permanent value for all time. His modesty and earnestness greatly impressed all those who took part in the proceedings here described, and, if a proof of this is demanded, it is enough to say that no one in authority mentioned the cost of the works, which is usually a prominent feature in the description of any benefaction.

\section{THE RECENT GROWTH OF POPULATION IN} WESTERN EUROPE.

$\mathrm{T}$ his inaugural address as president of the Royal Statistical Society, delivered in November last and published in the Journal of the Society for December, Sir. J. A. Baines deals in detail with the growth of the population of western Europe during the thirty years 1870-1900. The review covers the sixteen countries of western Europe properly so-called, excluding Russia, the countries of south-eastern Europe, and the "half-way" States of Hungary, Galicia, and Poland. In 1870 the population of western Europe so defined amounted in round numbers to 192 millions, a total which had increased by 1900 to 239 millionsan increment of nearly 25 per cent. But, as shown by the table below, the rate of increase was very different in different countries.

\begin{tabular}{|c|c|c|c|c|c|}
\hline \multirow{2}{*}{ Country } & \multirow{2}{*}{\multicolumn{2}{|c|}{$\begin{array}{l}\text { Total percent- } \\
\text { age increase } \\
\text { of population } \\
1870-1900\end{array}$}} & \multicolumn{3}{|c|}{$\begin{array}{l}\text { Average annual rates of increase } \\
\text { per thousand, } 1870^{-1900}\end{array}$} \\
\hline & & & Natural & Census & Leakage \\
\hline Sweden ... & $\ldots$ & $23 \cdot 2$ & $1 I^{\prime} 7$ & $7^{\circ} 0$ & 4.7 \\
\hline Norway... & $\ldots$ & $28 \cdot 9$ & 139 & $8 \cdot 5$ & $5 \cdot 4$ \\
\hline Finland... & $\ldots$ & $53 \cdot 3$ & $13^{\circ} 9$ & $13 \cdot 2$ & 0.7 \\
\hline Denmark & $\cdots$ & $36 \cdot 1$ & I 2.9 & $10 \cdot 3$ & $2 \cdot 6$ \\
\hline IHolland... & $\ldots$ & $43^{\circ} 2$ & 13.1 & 120 & $I \cdot I$ \\
\hline Belgium... & $\ldots$ & $33 \cdot 3$ & $9 \cdot 8$ & $9^{\circ} 6$ & 0.2 \\
\hline Germany & $\ldots$ & $38 \cdot I$ & 12.5 & 10.8 & $I \cdot 7$ \\
\hline West Austria & a... & $24: 4$ & $7 \cdot 8$ & $7 \cdot 7$ & 0.1 \\
\hline Switzerland & $\ldots$ & $24 \cdot 2$ & $7 \cdot 9$ & $7 \cdot 2$ & 0.7 \\
\hline England & $\ldots$ & $43 \cdot 2$ & $13^{\circ} 0$ & 120 & I'O \\
\hline Scotland & $\cdots$ & $33^{\circ} \mathbf{I}$ & 12.8 & $9 \cdot 6$ & $3 \cdot 2$ \\
\hline Italy & & $2 I^{\circ} 9$ & $9^{\circ} 4$ & $6 \cdot 6$ & $2 \cdot 8$ \\
\hline Spain & & I $2 \cdot 8$ & 49 & $4 \%$ & 0.9 \\
\hline Portugal & $\cdots$ & $24^{\circ} 2$ & 9.9 & $7 \cdot 3$ & $2 \cdot 6$ \\
\hline France ... & & 6.0 & $\mathrm{I} \cdot 4$ & 1.9 & +0.5 \\
\hline Ireland ... & $\ldots-$ & 17.6 & $6 \cdot 1$ & $-6 \cdot 5$ & \\
\hline Total .. & .. & $24^{\circ} 6$ & $8 \cdot 7$ & $7 \cdot 4$ & $I \cdot 3$ \\
\hline
\end{tabular}

France and Ireland are both very exceptional; the population of Ireland actually decreased by nearly i 8 per cent., while that of France increased by 6 per cent. only. In the Scandinavian countries, the increase ranged from 23 per cent. in Sweden to 36 per cent. in Denmark and 53 per cent. in Finland; in the central group from 24 per cent. in western Austria and Switzerland to 43 per cent. in England and Holland. In all countries except France, the natural rate of increase, by excess of births over deaths, has been greater than the actual rate of increase, the average annual rate of increase by excess of births over deaths amounting (as shown by the second column of the above table) to $8^{*} 7$ per thousand of the population; while the census only shows an average annual increase of $7^{\circ} 4$ per thousand. The loss, or "leakage," has been greatest in Ireland, and next greatest in Norway and Sweden; in all countries save Italy the rate of loss was greater in the decade $1880-90$ than in either the earlier or the later decade-in fact 
nearly three times as great-but the continuous increase in emigration from Italy has placed it of recent years at the head of the emigrating countries (Ireland excluded).

In all the countries considered, both birth- and deathrates have fallen, and in the majority, especially those countries (as Holland, Germany, and Austria) in which the death-rate at the commencement of the period was high, the fall in the deathrate has exceeded the fall in the birth-rate, as shown by the table below; the natural rate of increase was therefore greater at the end than at the beginning of the period, in spite of the fall in the birth-rate. England is one of the exceptional countries, for the death-rate, even at the commencement of the period, was moderate, and the fall in the birth-rate has rather more than kept pace with the fall in mortality.

\begin{tabular}{|c|c|c|c|c|}
\hline \multirow{3}{*}{$\begin{array}{c}\text { Country } \\
\text { Sweden ... }\end{array}$} & \multirow{2}{*}{$\begin{array}{c}\text { Mean annual } \\
\text { death-rate } \\
\text { per rosol } \\
1871-1900\end{array}$} & \multirow{2}{*}{$\begin{array}{c}\text { Mean annual } \\
\text { birth-rate } \\
\text { per 10001 } \\
1871-1900\end{array}$} & \multicolumn{2}{|c|}{$\begin{array}{l}\text { Decline per cent. in rates } \\
\text { between } 1871 \text { and } x 900\end{array}$} \\
\hline & & & Deaths & Births \\
\hline & $\ldots \quad 17 \cdot 2$ & $28 \cdot 9$ & $10 \% 4$ & II 2 \\
\hline Norway ... & $\ldots \quad 16.8$ & $30 \cdot 7$ & $4 \cdot I$ & $2 \cdot 3$ \\
\hline Finland ... & $\ldots \quad 2 \mathrm{r} \cdot \mathrm{O}$ & 347 & $1 \mathrm{I} \cdot 2$ & 130 \\
\hline Denmark & $\ldots \quad 18 \cdot 3$ & $31 \cdot 2$ & $10 \cdot 8$ & 39 \\
\hline Holland... & $\ldots \quad 2 I^{\circ} 2$ & $34 \cdot 3$ & $24 \cdot 3$ & II 4 \\
\hline Belgium... & $\ldots \quad 20.8$ & 305 & $150^{\circ}$ & $10 \cdot 2$ \\
\hline Germany & $\ldots \quad 24 \cdot 8$ & $37 \cdot 3$ & $18 \cdot 3$ & $7 \% 7$ \\
\hline West Austria & a... $27 \cdot 6$ & $3 ; 4$ & 13.3 & $6 \cdot 5$ \\
\hline Switzerland & $\ldots \quad 2 \mathrm{I} \cdot \mathrm{I}$ & $29^{\circ} 0$ & I9. I & $8 \cdot 7$ \\
\hline England & $\ldots \quad 19.6$ & $32 \cdot 6$ & 149 & 15.5 \\
\hline Scotland & $\ldots 19 \cdot 8$ & $32 \cdot 6$ & $13 \cdot 4$ & $12 \cdot 3$ \\
\hline Italy $\quad \ldots$ & $\ldots \quad 27 \cdot 1$ & $36 \cdot 5$ & $190^{\circ}$ & 5.4 \\
\hline Spain $\quad \ldots$ & $\ldots 30 \cdot 6$ & 35.5 & 36 & $2 \cdot 2$ \\
\hline Portugal... & $\ldots \quad 221$ & $32 \cdot 1$ & - & - \\
\hline France ... & $\ldots \quad 224$ & $23 \cdot 8$ & $9 \cdot 3$ & $12 \cdot 6$ \\
\hline Ireland $\ldots$ & $\ldots \quad 18 \cdot 2$ & $24 \cdot 3$ & $\mathrm{I} \cdot \mathrm{I}$ & $13 \cdot 2$ \\
\hline Total . & . 23.8 & $32 \cdot 5$ & 13.7 & $6 \cdot 6$ \\
\hline
\end{tabular}

The factors contributing to the fall in the birth-rate, which has recently attracted so much attention, are analysed in detail by Sir Athelstane Baines. For the most part it is clearly due to a fall in the fecundity of married women of reproductive age. The proportion of women of reproductive age to the population has in many countries (as in the United Kingdom) slightly increased, in other cases remained almost steady or fallen very little. The proportion of such women who are married, as shown by the table below,

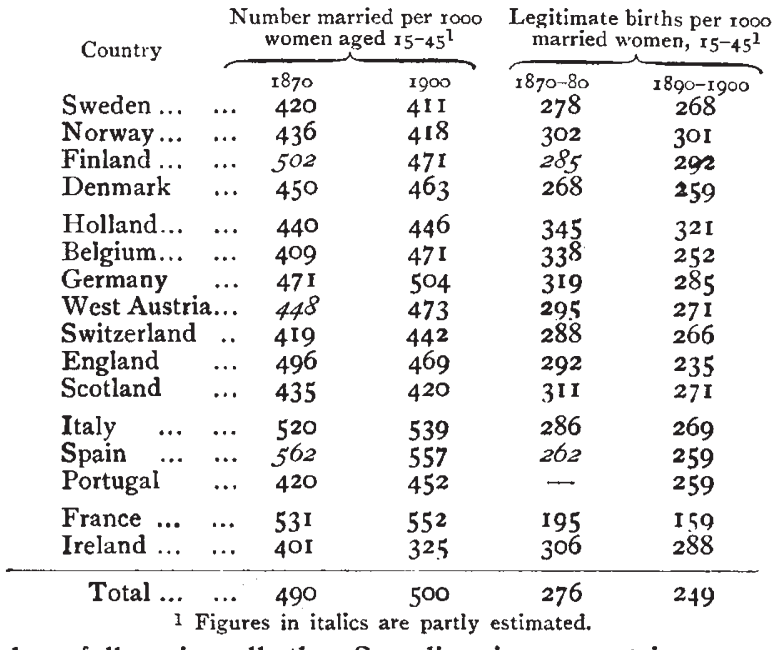

has fallen in all the Scandinavian countries save Denmark, but has increased in all the countries of the central group, except England and Scotland. The births per thousand married women of fertile ages, on the other hand, have fallen in every country, with the sole exception of Finland (and perhaps one should add Norway), and most markedly in the central European group.

"The thirty years included in my survey," Sir Athelstane Baines concludes, " have been generally characterised by a moderate rate of growth of population, interrupted until towards the end of that period by considerable emigration, since reduced, except in one or two cases. People marry a little more than they did a generation ago, and, in most of the countries reviewed, they marry earlier; but the growth in the relative number of the married has been accompanied by a material decline in their output of children. Illegitimate unions, also, whether less frequent than before or not, at least contribute less to the tale of births. The community is therefore almost everywhere becoming an older one, with a gradually decreasing basis for the coming generation. Thanks to a general improvement in hygienic conditions, fewer succumb to disease, especially in early life, and the mortality having decreased more rapidly than the fertility of the population, the excess of births over deaths is relatively not below, but, on the whole, indeed, a little above that which prevailed at the beginning of the period."

\section{PROF. HANS LANDOLT.}

N March $1_{5}$, Geheimrat Prof. Landolt, the Nestor of physical chemists, passed to his rest, full of years and of honours. How few are left now of that ardent band who, in the early 'fifties, came under Bunsen's inspiration in romantic Heidelbers!

In a brief notice it is impossible to give an adequate picture either of the man or of his deeds. One is glad to think, however, that his devotion to science will be recognised in the memorial lectures by which the various societies strive to do honour to the memory of distinguished investigators.

Hans Heinrich Landolt was born in Zürich in $183 \mathrm{r}$, and began the study of chemistry in the university of his native town. His Wanderjahre were spent in Breslau, where he graduated, in Berlin, where he studied under Rose and Mitscherlich, and, finally, in Heidelberg. His progress in the academic career was rapid. He became a Privatdozent in Breslau (I856), an extraordinarius professor in Bonn ( $\left.185^{8}\right)$, and an ordinarius professor in Bonn (1867). He then proceeded to the Technische Hochschule in Aachen. In 1880 we find him in Berlin, where he occupied the chair of chemistry in the Landwirtschaftliche Hochschule until, in I89I, he succeeded Rammelsberg as director of the second chemical institute of the university. When old age came upon him, his enthusiasm did not wane; he was active to the last.

Landolt's researches were by no means confined to one branch. In organic chemistry he studied, for example, compounds of arsenic and antimony, the action of potassium amide on various carbon compounds, and the chemical changes in the flame of coal gas. In inorganic chemistry he dealt with subjects such as phosphine, solid carbon dioxide, ammonium amalgam, thiosulphurous acid in aqueous solution, the interaction of bromine and nitric oxide. It is, however, on his pioneering experiments on molecular refraction and optical activity that his fame as an investigator will last for all time. With the exception of the contributions of Biot, very little of importance had been done on the measurement of the specific rotations of optically active substances until the field was taken up by Landolt in a series of papers which are models of exactitude. As a consequence of the experience he gained, workers in stereochemistry are indebted to him for numerous improvements in the technique of polarimetric observation.

NO. 211 I, VOL. 83] 